\title{
PARTIAL AND TOTAL DISAGGREGATION FRAMEWORK OF A SECOND-ORDER CONSTRUCT OF ORGANISATIONAL CULTURE
}

\author{
Amin Wibowo \\ Faculty of Economics and Business \\ Universitas Gadjah Mada Yogyakarta \\ e-mail: amin.wibowo@gadjahmada.edu
}

\begin{abstract}
An important issue in organisational research is the assessment of constructs' validity of measure or depth. Several methods are widely available but researchers have come to acknowledge the power of confirmatory factor analysis in investigating the construct validity of a measure. In this paper, the total disaggregation (TD) and (partial disaggregation) PD models were applied in an effort to provide an empirical comparison of second-order construct measurement under these methods. The second-order construct of organisational culture consisted of five first-order constructs. Results indicated that, in general, the two models produced quite similar results. The requirements of convergent validity and construct scale reliability were satisfied; discriminant validity tests were fulfilled; and overall goodness-of-fit indices satisfied the benchmark applied. Thus, analyses supported the use of the second-order constructs of organisational culture and provided scholars an example of these models being examined in structural equation modelling.
\end{abstract}

Key words: Structural Equation Modelling, Partial Disaggregation, Total Disaggregation, Secondorder Construct, Organisational Culture.

\begin{abstract}
Abstrak
Satu hal yang penting dalam penelitian organisasi adalah penilaian validitas konstruk ukuran atau kedalamannya. Beberapa metode tersedia secara luas namun para peneliti telah berkesimpulan untuk mengakui kekuatan analisis faktor konfirmatori dalam menyelidiki validitas konstruk ukuran. Dalam tulisan ini, model pemilahan total (Total Dissagregation) dan pemilahan parsial (Partial Dissagregation) diterapkan dalam upaya untuk memberikan perbandingan empiris pengukuran konstruk dua tingkat (second-order construct) di bawah kedua metode ini. Konstruk dua tingkat budaya organisasi terdiri dari lima konstruk tingkat pertama. Hasil penelitian menunjukkan bahwa, secara umum, kedua model menghasilkan hasil yang sangat mirip. Persyaratan validitas konvergen dan reliabilitas skala konstruks dipenuhi, diskriminan uji validitas terpenuhi, dan keseluruhan indeks kebaikan (goodness-of-fit indices) memenuhi patokan yang diterapkan. Dengan demikian, analisis mendukung penggunaan konstruks dua tingkat budaya organisasi dan menyediakan contoh bagi para ahli bagaimana model ini diterapkan dalam pemodelan persamaan struktural.
\end{abstract}

Kata kunci: Persamaan Pemodelan Struktural, Pemilahan Parsial, Pemilahan Total, Konstruks dua tingkat, Budaya Organisasi.

\section{INTRODUCTION}

The purpose of this study is to demonstrate the applications of Partial Disaggregation (PD) and Total Disaggregation (TD) in developing a second-order model of the organisational culture construct. These analyses were performed using the LISREL program developed by Jöre- skog and Sorbom (Jöreskog, 1970; Jöreskog and Sörbom, 2006).

One of the important issues in organisational research is the assessment of the validity of the measure of a construct (Bagozzi et al., 1991) or construct depth (Bagozzi and Edwards, 1998). Although several methods are widely available (e.g. exploratory factor analy- 
sis, multitrait-multimethod matrix), many researchers acknowledge the power of confirmatory factor analysis in investigating the construct validity of a measure (Marsh and Hocevar, 1985; Bagozzi et al., 1991; Rahim and Magner, 1995). There are considerable debates and uncertainties about the extent to which the organisational construct should be operationalised. Single-faceted and multi-faceted constructs derived from conceptual development are subject to tests as a way of providing sound abstraction. Bagozzi and Heatherton (1994) were among the first to raise this issue in organisational research. They proposed four levels of abstraction, namely the total aggregation, partial aggregation, partial disaggregation and total disaggregation models. Further, Bagozzi and Edwards (1998) highlighted the issue of depth in developing constructs of organisational research. Using the same four levels of abstraction, they showed the appropriate depth in terms of the specificity and generality of a construct and its associated operationalisation. According to them, it is essential to have construct depth if meaningful results are to be obtained. More recent studies on the issue of construct validity or depth can be seen in the work of Meade, Michels, and Lautenschlager (2007), Perriatt et al. (2007), Bobbio and Rattazzi (2006), and Gana and Trouillet (2003), among many others. However, it must be noted that these above studies are not discussing the issue of construct validity in the higher level of abstraction (second-order construct)-they were discussing the construct validity's issue at lower level (first-order construct). The goals of this paper is to illustrate confirmatory factor analysis-including construct validity under Partial and Total Disaggregation levels of abstraction in a second-order construct. The illustration provide here can be used as example of two levels of abstraction as there has been limited study investigating this issue.

\section{Partial Disaggregation (PD) and Total Dis- aggregation (TD) Models}

The term Partial Disaggregation (PD) represents the fact that items for a construct or component are split into sets (usually two) of aggregated items. With such a model, items are initially aggregated (through summation or averaging) to create item 'packets' or composites, which are then used as indicators of model constructs. The second-order PD model illustrated in Figure 1 treats the components as first-order factors and introduces a second-order factor explaining variation in the first-order factor (Bagozzi and Heatherton, 1994). The secondorder factor can be thought of as an abstract representing organisational culture. The second-order construct of organisational culture consists of five first-order constructs namely autonomy (Auto), external orientation (EO), interdepartmental coordination (IDC), human resource management (HRM), and improvement orientation $(I O)$. The five dimensions of organisational culture are reflected by $a$ and $b$ indicators, which were calculated by averaging the measured items of each factor.

The term Total Disaggregation (TD) refers to the condition that each indicator is an individual item. The second-order TD model is demonstrated in Figure 2. The main difference between PD and TD is the way each treats the measured items for the first-order constructs. TD uses individual items from the first-order constructs of the organisational culture to operationalise their respective hypothesised dimensions. No average calculation is taken in this model. Accordingly, the number of measured items in each of the first-order is not two of the average items, but varies depending upon the conceptual development of the construct.

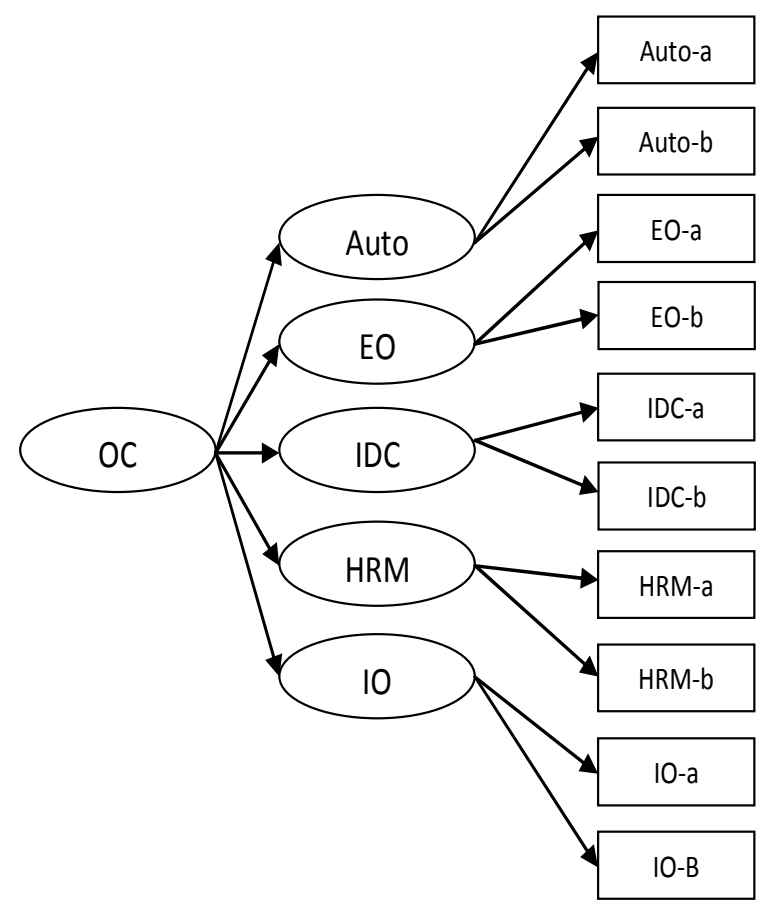

Figure 1: Partial Disaggregation Model 


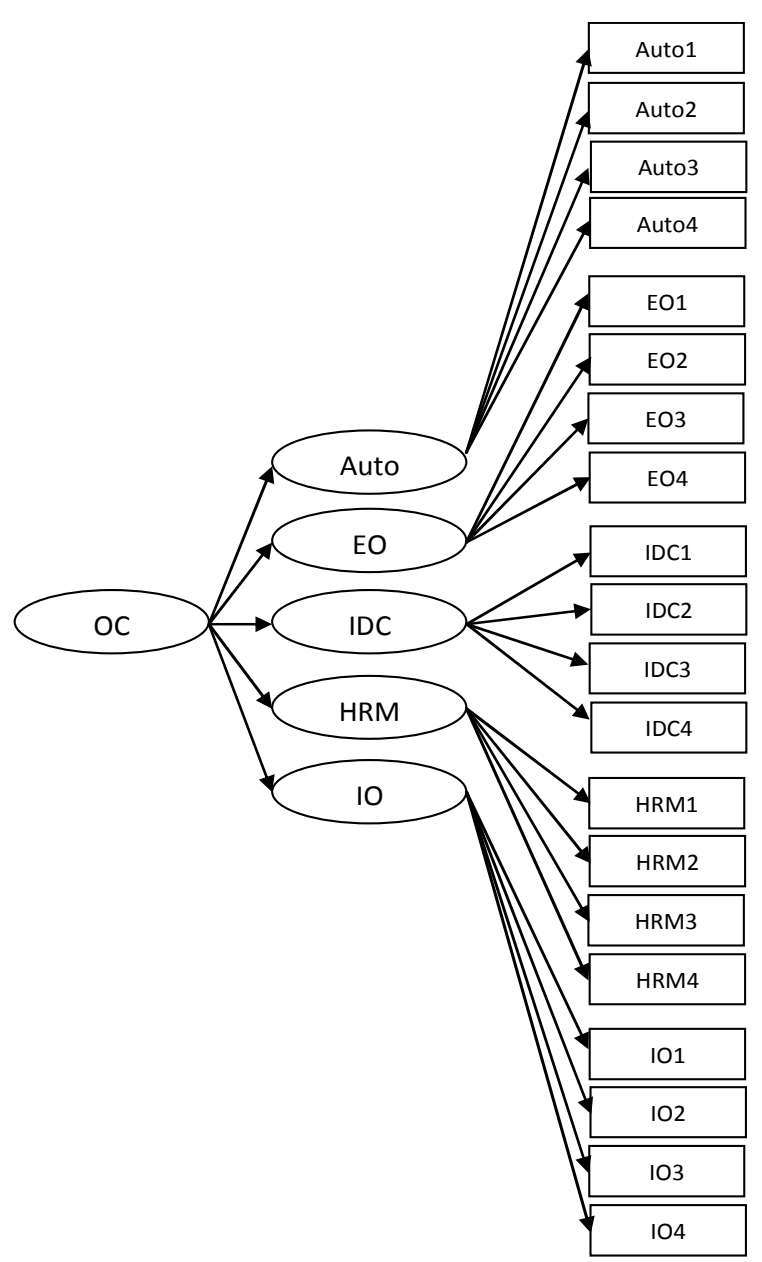

Figure 2Total Disaggregation Model

In discussing the advantages and disadvantages of PD and TD, researchers have offered various explanations. Marsh and Hocevar (1985) stated that the main advantage of second-order PD is that hypotheses can be tested about the hierarchical structure of the construct. Another advantage was claimed by Bagozzi and Edwards (1998) who stated that PD reduces the number of parameters to be estimated and, at the same time, tends to decrease measurement error. In comparison to TD, smaller sizes are required with $\mathrm{PD}$ and the model generally yields better fit (Landis, Beal, and Tesluk 2000).

In addition, Bagozzi and Heatherton (1994) stated that PD permits interesting inquiries into discriminant validity among the dimensions of a construct. A possible downside of this 'molecular' model is it does not provide the specific psychometric information concerning each individual item that the more 'atomistic' representation of the total disaggregation approach provides. Bagozi and Heatherton (1994) also acknowledged the possibility of encountering a problem with discriminant validity, as 'discriminant validity among dimensions may be less defensible, and the dimensions should be interpreted as sub-components of a higher order organizing concept'.

In contrast, the TD model provides the most detailed level of analysis of a construct, because psychometric properties are provided for each individual item (Bagozzi and Heatherton 1994; Bagozzi and Edwards, 1998). However, in practice this model 'can be unwieldy because of likely to have high levels of random error in typical items and the many parameters that must be estimated' (Bagozzi and Heatherton, 1994). In addition to this disadvantage, Caro and Garcia (2007) stressed that although TD allows the most explicit test of construct quality, it lacks a number of features of the PD model. For example, the PD is used to decrease the number of parameter estimates with respect to sample size, to reduce the likelihood of computational problems and to obtain smaller standard errors. As a result it is possible to have a TD model that may fail to fit the data satisfactorily.

\section{Organisational Culture Construct}

The terms 'organisational culture' and 'corporate culture' were introduced to the academic literature by Pettigrew (1979) and Silverzweig and Allen (1976), respectively. It seems that the popularity of these terms grew because of the work of Peters and Waterman (1982). Since then, an enormous literature has developed on these topics. Although no conclusive definitions have been widely agreed upon among researchers, there are common characteristics of culture which involve some combination of artefacts (also called practices, expressive symbols or forms), values and beliefs, and underlying assumptions that organisational members share about appropriate behaviour (Schein, 1992). In this study, organisational culture is defined as "particular ways of conducting organisational functions that have evolved over time under the influence of an organisation's history, people, interests, and actions and that have become institutionalized in the organisation' (Kostova, 1999). This definition portrays the perceptions of organisational work practices 
within an organisation. Here, organisational practices are believed to reflect the 'collective wisdom within an organisation about how things can best be done' (Wilderom and Van den Berg, 2005). Further, these practices are viewed as ways of doing certain tasks that are taken-for-granted (Kostova, 1999).

The organisational culture construct operationalised in this study was developed from the studies of Van den Berg and Wilderom (2004) and Wilderom and Van den Berg (1998). Then, additional items were added to better portray the domain of the organisational culture construct. In accordance with the dimensions used in this study, Detert, Schroeder and Mauriel (2000), who performed a qualitative content analysis of the extant literature, lend support to utilising these dimensions in researching organisational culture. The dimension of Autonomy (Auto) was selected because it refers to the freedom of employees to contribute the skills they have in advancing the company. This dimension was also used by Gordon and DiTomaso (1992), who called it 'accountability and systematic decision making' and Detert et al. (2000), who termed it 'control, coordination, and responsibility'. The External Orientation (EO) dimension is similar to willingness and effort taken to quickly anticipate and respond to customers' demands. The work of Hofstede et al. (1990) termed this an 'open vs. closed system'; and the research of Detert et al. (2000) called it 'orientation and focus-internal and/or external' - each of which can refer to this dimension. The dimension of Inter-Departmental Coordination (IDC) was chosen since modern organisations commonly have divisions of work, which increase the flow of work and information among members. As a result of increasing barriers, an organisation's functioning is likely to be adversely influenced. Previous studies which support the use of this dimension are O'Reilly et al. (1991), who used the term 'team oriented', and Detert et al. (2000) who named it 'isolation versus collaboration/cooperation'. The Human Resource Management (HRM) dimension has been considered as one aspect of organisational culture by many researchers in the past. Van Muijen et al. (1999) named it 'support orientation', and Detert et al. (2000) termed it 'orientation to work, task, and coworkers'. This dimension covers the process of employees' selection, the support to employees' functioning and whether performance mechanisms were in place. Reflecting humans' ambition, Improvement Orientation $(I O)$ is utilised in this study. Most people are stimulated to achieve a better result, both for themselves and their company. Backing the use of this dimension are the studies of Van Muijen et al. (1999), who labelled it 'innovation orientation', and Detert et al. (2000), who named it 'stability versus change/innovation/personal growth'.

\section{METHOD Sample}

One thousand questionnaires were distributed to managers and/or executives representing Indonesian companies. An average total asset of these firms was US\$4,387,297,000. Thirty eight per cent of these firms belonged to bank/financial firms, and the remaining percentage were member of manufacturing/processing firms. Of the 1000 surveys sent, 669 were collected. This was equivalent to 66.9 per cent of initial response rate. However, of the 669 questionnaire returned, 173 were ineligible because of the incomplete response in more than three items in every construct's list of questions, and thus discarded. This resulted to 496 usable responses or 49.6 per cent of effective response rate. These 496 useable questionnaires were tabulated for statistical data analysis. Relating to age of respondents, more than half $(47.2 \%)$ were between 30 and 40 years of age, 28 per cent were between 40 and 50, 13.7 per cent were under $30,10.7$ per cent were between 50 and 60 , and only 0.4 per cent were above 60 years old. Further, 28.4 per cent had worked for their current company for $5+$ to 10 years, 24.2 per cent of respondents had been in their current company for $10+$ to 15 years, 18.1 per cent for 1 to 5 years, 15.1 per cent for more than 20 years, 12.1 per cent for $15+$ to 20 years, and 2.0 per cent for less than 1 year.

\section{Measurement}

The dimensions of organisational culture developed by Van den Berg and Wilderom (2004) and Wilderom and Van den Berg (1998) were used as primary references. In regard to the $E O$ dimension, items proposed by Nahm, Vonderembse and Koufteros (2004) were added; the IDC dimension was improved by adding 
items used by Nahm et al. (2004) and Denison (1990); HRM dimension was improved with items proposed by Hofstede (1990); and $I O$ dimension was improved with items proposed by Denison (1990) and Hofstede et al. (1990). Once the measures had been developed, the organisational culture second-order construct consisted of 5 dimensions and 20 observed variables. In regard to the scale, the study asked participants to express the extent of their agreement or disagreement using a six-point Likert type scale, ranging from strongly agree to strongly disagree.

In regard to the scale, the study asked participants to express the extent of their agreement or disagreement using a six-point Likert-type scale, ranging from strongly agree to strongly disagree. The utilisation of a sixpoint scale instead of a five- or seven-point scale was based on the argument advanced by Trompenaars and Hampden-Turner (1997), who provided evidence that some Asian countries, including Indonesia, rank high in the neutrality dimension. Consequently, the middle choice of response - namely 'neutral' and 'neither agree or disagree' - was excluded. It was believed that such responses would have contributed to the central tendency error (Coper and Schindler, 2003).

\section{Statistical Criteria}

The extent to which the model proposed corresponds to the data can be evaluated through the use of several goodness-of-fit indices. Two groups of indices, namely absolute and comparative indices, are available. For this study, the following indices were applied, representing absolute and comparative indices assessment:

\section{Root Mean Square Error of Approximation (RMSEA)}

Alike RMR, RMSEA is the discrepancy per degree of freedom, but, it differs from RMR in that the discrepancy is measured in terms of the population, not just the sample utilised for estimation (Steiger 1990). Holmes-Smith noted that RMSEA will consider the error of approximation in the population and relaxes the strict requirement on Chi-Square that the model holds exactly in the population (2001). To be classify adequately fit, the model should has a value of RMSEA of less than .05 (although values between .05 and .08 indicate reasonable fit) (Holmes-Smith, 2001). Other recommends cut-off value of $\leq .06$ ( $\mathrm{Hu}$ and Bentler 1999). Another characteristic of RMSEA is also among the measures least affected by sample size (Fan et al., 1999).

\section{Goodness of Fit Index (GFI)}

GFI is most widely used goodness-of-fit measure in many studies of SEM. It "measures the absolute fit (unadjusted for the degrees of freedom) of the combined measurement and structural model to the data' (Gefen et al., 2000). The acceptable level of GFI is to have values greater than .95 , although the values of .90 is deemed reasonable fit (Holmes-Smith, 2001).

\section{Adjusted Goodness of Fit Index (AGFI)}

To complement the measure of goodness-of fit indices, the AGFI is proposed. AGFI adjusts the values GFI for the degree of freedom in the model (Gefen et al., 2000). Threshold for this index is greater than .90 or .95 (Holmes-Smith, 2001).

\section{Comparative Fit Index (CFI)}

Comparative Fit Index (CFI) was suggested by Bentler (1990) with the purpose to overcome the deficiencies in normed fit index (NFI) for nested model. The NFI has tendency to underestimate fit in small size sample (Byrne, 2006). Here, the comparative fit index is comparing whether the model under consideration is better than some baseline model, which in most cases are null or independence model. The CFI ranges should fall between 0 and 1 , with values exceeding .90 indicating a good fit to the data (Kelloway, 1998). In case where the values of CFI is above 1 then there is indication that the model is overfit as there are too many parameters have been freed to be estimated (HolmesSmith, 2001).

\section{Non-Normed Fit Index (NNFI)}

Non-Normed Fit Index (NNFI) is one of the fit indexes less affected by sample size. The NNFI takes into account the degrees of freedom of the proposed model, and hence the complexity of the model. The complex models have more parameters and fewer degrees of freedom. By convention, NNFI values below .90 indicate a 
need to respecify the model. More recently, $\mathrm{Hu}$ and Bentler (1999) have suggested NNFI $\geq .95$ as the cut-off for a good model fit.

\section{RESULTS \\ Measurement Convergent Validity}

This validity was assessed by examining the factor loading of each item on its specified factor (Anderson and Gerbing, 1988). For the PD model, factor loadings were significant, with $t$ values ranging between 8.63 and 94.26. For the TD model, factor loadings were also significant, with $t$-values ranging from 8.43 to 77.84 . Accordingly, the requirement of convergent validity was satisfied.

\section{Construct Scale Reliability and Variance Ex- tracted Estimate}

In assessing the reliability of multiple measures for an individual construct, the internal consistency measure developed by Fornell and Larcker (1981) was applied. Another measure of construct reliability is the variance extracted estimate, which reflects the overall amount of variance in the indicators accounted for by the latent construct. The variance extracted measure is a complementary measure to the construct reliability. Guidelines suggest that the acceptable reliability and variance extracted values should exceed .50 for a construct (Hair et al., 1998; Holmes-Smith, 2001).
Results in Table 1 indicated that all constructs had good construct reliability (>.50). All but one had variance extracted estimates $>$.50. The construct that had a variance extracted estimate less than .50 was Auto, under the TD model (0.403). Given this, there was the possibility of dropping this construct from subsequent analysis. However, considering that the construct reliability of the construct Auto was very good (0.614) and that variance extracted estimate is a complementary measure, the study decided to maintain this construct.

\section{Discriminant Validity}

In assessing discriminant validity, two tests were applied. First, constructs are supposed to be not highly correlated, as they are measuring different concepts. Therefore, a correlation between constructs that is greater than .80 or .90 represents a lack of discriminant validity (HolmesSmith 2001). Second, comparing the average variance extracted (AVE) with the square of correlation (SC) between constructs, AVE should be greater than $\mathrm{SC}$ if discriminant validity is to be in place (Fornell and Larcker 1981).

Results indicated that, firstly, none of the correlations between constructs was higher than the threshold of .80 (Table 2). Secondly, all average variance extracted (AVE) was greater than their square of correlation (SC). Accordingly based on these results, the discriminant validity of this study was satisfied (Table 3).

Table 1: Construct Scale Reliability and Variance Extracted Estimate

\begin{tabular}{lcccc}
\hline \multicolumn{1}{c}{ Constructs } & \multicolumn{2}{c}{ Construct Scale Reliability } & \multicolumn{2}{c}{ Variance Extracted Estimate } \\
\hline & $\mathrm{PD}$ & $\mathrm{TD}$ & $\mathrm{PD}$ & $\mathrm{TD}$ \\
Autonomy & 0.749 & 0.724 & 0.614 & 0.403 \\
External Orientation & 0.838 & 0.864 & 0.722 & 0.616 \\
Inter-departmental Coordination & 0.856 & 0.854 & 0.748 & 0.597 \\
Human Resource Management & 0.877 & 0.870 & 0.781 & 0.626 \\
Improvement Orientation & 0.894 & 0.897 & 0.811 & 0.685 \\
\hline
\end{tabular}

Table 2: Intercorrleations of Latent Variables: PD and TD Model

\begin{tabular}{cccccc}
\hline & Auto & EO & IDC & HRM & IO \\
\hline Auto & 1.000 & 0.360 & 0.370 & 0.330 & 0.310 \\
EO & 0.410 & 1.000 & 0.620 & 0.640 & 0.610 \\
IDC & 0.430 & 0.700 & 1.000 & 0.760 & 0.640 \\
HRM & 0.370 & 0.630 & 0.780 & 1.000 & 0.700 \\
IO & 0.390 & 0.590 & 0.660 & 0.710 & 1.000 \\
\hline
\end{tabular}

Note: Correlations above the diagonal are under PD Model. Correlations below the diagonal are under TD Model. 
Table 3: Discriminant Analysis PD and TD (AVE > SC?)

\begin{tabular}{lllclccc}
\hline \multicolumn{7}{c}{} & \multicolumn{3}{c}{$\begin{array}{c}\text { PD Model } \\
\text { Con- } \\
\text { structs }\end{array}$} & $\begin{array}{c}\text { Average } \\
\text { Variance } \\
\text { Extracted } \\
\text { (AVE) }\end{array}$ & $\begin{array}{c}\text { Square of } \\
\text { Correlation } \\
\text { between } \\
\text { Construct } \\
\text { (SC) }\end{array}$ & $\begin{array}{c}\text { AVE } \\
\text { >SC? }\end{array}$ & $\begin{array}{c}\text { Average } \\
\text { Variance } \\
\text { Extracted } \\
\text { (AVE) }\end{array}$ & $\begin{array}{c}\text { Square of } \\
\text { Correlation } \\
\text { between } \\
\text { Construct } \\
\text { (SC) }\end{array}$ & $\begin{array}{c}\text { AVE } \\
\text { >SC? }\end{array}$ \\
\hline Auto with & EO & 0.568 & 0.130 & Yes & 0.512 & 0.168 & Yes \\
& IDC & 0.699 & 0.137 & Yes & 0.503 & 0.185 & Yes \\
& HRM & 0.709 & 0.109 & Yes & 0.517 & 0.137 & Yes \\
& IO & 0.675 & 0.096 & Yes & 0.549 & 0.152 & Yes \\
EO with & IDC & 0.737 & 0.518 & Yes & 0.607 & 0.490 & Yes \\
& HRM & 0.756 & 0.410 & Yes & 0.619 & 0.397 & Yes \\
& IO & 0.774 & 0.372 & Yes & 0.650 & 0.348 & Yes \\
HRM with & HRM & 0.765 & 0.578 & Yes & 0.611 & 0.608 & Yes \\
& IO & 0.783 & 0.410 & Yes & 0.641 & 0.436 & Yes \\
& IO & 0.792 & 0.490 & Yes & 0.657 & 0.508 & Yes \\
\hline
\end{tabular}

\section{Overall Goodness-of-Fit-Indices}

Table 4 shows the indices that were used to assess the extent to which the model fit with the data. Most of the fit indices satisfied the benchmark applied to this study. In regard to the GFI and the AGFI of the TD Model, it is acknowledged that these indices were less than the restrictive threshold of .90 . As previously highlighted, it is possible to have a TD model that may not yield fit indices satisfactorily. However, if other indices perform well, it is still appropriate to conclude that overall fit indices do well.

Table 4: LISREL Summary of Goodness-of-Fit Indices

\begin{tabular}{lrr}
\hline \multirow{2}{*}{ Statistics } & \multicolumn{2}{c}{ Measurement } \\
\cline { 2 - 3 } & \multicolumn{1}{c}{ PD } & \multicolumn{1}{c}{ TD } \\
\hline$\chi 2$ & 227.863 & 1167.693 \\
df & 183 & 871 \\
RMSEA & 0.022 & 0.026 \\
GFI & 0.934 & 0.801 \\
AGFI & 0.909 & 0.774 \\
CFI & 0.998 & 0.997 \\
NNFI & 0.998 & 0.997 \\
\hline
\end{tabular}

\section{Discussion}

Evidence from the measurement part showed that the models used for developing the secondorder constructs of organisational culture produced models with varying degrees of fit. The findings show that construct can be represented in a statistically sound way and that their meas- ures achieve convergent and discriminant validity under two different models. Under the PD model, the level of abstraction is less concrete as there are only two averaging items per construct. The evidence, however, suggested that there were no problems with factor loadings as $t$-values were all significant. Construct scale reliability and the variance extracted estimate for each construct under this model also showed good results. The indicators for the discriminant validity tests were also good. Under the TD model, the level of abstraction is more concrete as the numbers of items are not compressed to two, but rather vary depending upon the conceptual development of the construct. The results under this model were in general also acceptable. All factor loadings were significant, confirming convergent validity of the construct used for this study. Construct scale reliability of each of the constructs for the TD model also showed good results. All but one variance extracted estimate was higher than the benchmark of .50. The Auto construct had a variance extracted estimate of .403 . As the result of construct scale reliability was very good, this construct was maintained for further analyses. The TD model also passed the discriminant validity tests.

In regard to goodness-of-fit indices, the PD model provided better figures than the TD model. Strong evidence for the validity of the construct was indicated by all goodness-of-fit indices in the PD model. Under the TD model, RMSEA, CFI and NNFI performed very well. 
However, there was concern relating to the GFI and the AGFI. The GFI and the AGFI descriptive indices range between 0 and 1 , and are usually fairly close to 1 for well-fitting models. Unfortunately, as with many other indices, no strict norms for GFI and AGFI exist below which a model cannot be considered a plausible description of the analysed data and above which one can rest assured that the model approximates the data reasonably well (Raykov and Marcoulides, 2006). Thus, considering other indices surpass their benchmarks, it is considered that the TD model can be used for further analysis.

The results enhance the utility of the organisational culture instruments by presenting confirmation that both constructs explain and measure the second-order construct of organisational culture. The major advantage of this higher (secondary) level analysis is that the theory underlying the latent constructs can be meaningfully extended to practical applications (Babakus et al., 2004). The second-order constructs of organisational culture can now be used as standardised measures. In sum, researchers and managers can now use these items with confidence, as they have adequate validity and reliability.

\section{Conclusion}

The purpose of this paper is to demonstrate the applications of Partial Disaggregation (PD) and Total Disaggregration (TD) in developing a second-order model of the organisational culture construct. Results indicated that using five dimensions namely autonomy, external orientation, inter-departmental coordination, human resource management, and improvement orientation, the benchmarks for validity testconvergent validity, construct scale reliability, variance extracted, and discriminant validityall were satisfied. TD with the level of abstraction which is more concrete compared to PD slightly produced lower benchmark for variance extracted estimate. But considering all indicators were very good, in general TD passed the benchmarks applied. Goodness-offit Indices to assess the extent to which the model fit with the data for both models also were very good.

The findings showed that organisational culture construct can be represented in a statistically sound way under PD and TD model. Researchers can use higher (secondary) level analysis in assessing the theory underlying the construct of organisational culture. As many constructs in behavioural sciences represented in more abstract ways (in the form of latent variables and multifaceted), the result of this study may be used as one of example in regard to the assessment of constructs' validity of measure in structural equation modelling.

\section{REFERENCES}

Anderson, JC. and DW. Gerbing. 1988. Structural Equation Modeling in Practice: A Review and Recommended Two-Step Approach. Psychological Bulletin. 103 (3). 411-423.

Babakus, E., S. Eroglu and U. Yavas. 2004. Modeling Consumers' Choice Behavior: An Application in Banking. The Journal of Service Marketing. 18 (6/7). 462-470.

Bagozzi, RP. and JR. Edwards. 1998. A General Approach for Representing Constructs in Organizational Research. Organizational Research Methods. 1. 4587.

Bagozzi, RP. and TF. Heatherton. 1994 A General Approach to Representing Multifaceted Personality Constructs: Application to State Self-Esteem. Structural Equation Modeling. 1. 35-67.

Bagozzi, RP., Y. Yi and LW. Phillips. 1991. Assessing Construct Validity in Organizational Research. Administrative Science Quarterly. 36(3). 421-458.

Banks, E. 2004. Corporate Governance: Financial Responsibility, Controls and Ethics New York. Palgrave Macmillan.

Bentler, PM. 1990. Comparative Fit Indexes in Structural Models. Psychological Bulletin. 107 (2). 238-246.

Bentler, PM. 1995. EQS Structural Equations Program Manual. Encino. CA. Multivariate Software.

Bhagat, S. and B. Black. 2002. The NonCorrelation between Board Independ- 
ence and Long-Term Firm Performance. Journal of Corporation Law. 27 (2). 231-273.

Bobbio, A. and AMM. Rattazi. 2006. A Contribution on the Validation of Motivation to Lead Scale (MTL): A Research in the Italian Context. Leadership. 2. 117129.

Byrne, BM. 2006. Structural Equation Modeling with EQS: Basic Concepts, Applications, and Programming. $2^{\text {nd }}$ ed. New Jersey. Lawrence Erlbaum Associates, Inc.

Caro, LM. and JAM. Garcia. 2007. Measuring Perceived Service Quality in Urgent Transport Service. Journal of Retailing and Consumer Services. 14. 60-72.

Cascio, WF. 2004. Board Governance: A Social Systems Perspective. Academy of Management Executive. 18 (1). 97-100.

Cooper, DR. and PS. Schindler. 2003. Business Research Methods. 8th ed. New York. McGraw Hill.

Daniri, MA. 2005. Good Corporate Governance: Konsep dan Penerapannya dalam Konteks Indonesia. Jakarta. PT. Ray Indonesia.

Desai, A., M. Kroll and P. Wright. 2003. CEO Duality, Board Monitoring, and Acquisition Performance: A Test of Competing Theories. Journal of Business Strategies, 20 (2). 137-156.

Detert, JR., RG. Schroeder and JJ. Mauriel. 2000. A Framework for Linking Culture and Improvement Initiatives in Organizations. Academy of Management Review, 25 (4) 850-863.

Fan, X., B. Thompson and L. Wang. 1999. Effects of Sample Size, Estimation Method, and Model Specification on Structural Equation Modeling Fit Indexes. Structural Equation Modeling: A Multidisciplinary Journal. 6 (1) 5683.

Fornell, C. and DF. Larcker. 1981. Evaluating Structural Equation Models with Unobservable Variables and Measurement
Error. Journal of Marketing Research. 18. 39-50.

Gana, K. and R. Trouillet. 2003. Structure Invariance of the Temperament and Character Inventory (TCI). Personality and Individual Differences. 35. 14831495.

Gefen, D., DW. Straub and M. Boudreau. 2000. Structural Equation Modeling and Regression: Guidelines for Research Practice. Communication of the Association for Information Systems. 4. 1-77.

Gill, M., RJ. Flynn and E. Reissing. 2005. The Governance Self-Assessment Checklist: An Instrument for Assessing Board Effectiveness. Nonprofit Management and Leadership. 15 (3) 271-294.

Gomez-Mejia, LR. and HG. Barkema. 1998. Managerial Compensation and Firm Performance: A General Research Framework. Academy of Management Journal. 41. 135-145.

Gordon, GG. and N. DiTomaso. 1992. Predicting Corporate Performance from Organizational Culture. Journal of Management Studies. 29 (6). 783-798.

Hair, JF., RE. Anderson, RL. Tatham and WC. Black. 1998. Multivariate Data Analysis, 5th ed. New Jersey. Prentice-Hall International, Inc.

Hermalin, BE. and MS. Weisbach. 2003. Boards of Directors as an Endogenously Determined Institution: A Survey of the Economic Literature. FRBNY Economic Policy Review. April. 7-26.

Hofstede, G. 2004. Business Goals and Corporate Governance. Asia Pacific Business Review. 10 (3/4). 292-301.

Hofstede, G., B. Neuijen, DD. Ohavy and G. Sanders. 1990. Measuring Organizational Cultures: A Qualitative and Quantitative Study across Twenty Cases. Administrative Science Quarterly. 35 (2). 286-316. 
Holmes-Smith, P. 2001. Introduction to Structural Equation Modeling Using LISREL. Perth. 2 July-6 July 2001.

Hu, Li-tze, and PM. Bentler. 1999. Cutoff Criteria for Fit Indexes in Covariance Structure Analysis: Conventional Criteria Versus New Alternatives. Structural Equation Modeling: A Multidisciplinary Journal. 6 (1). 1-55.

Jöreskog, KG. 1970. A General Method for Analysis of Covariances Structures. Biometrika. 57. 239-251.

Jöreskog, KG. and D. Sörbom. 2006. Interactive LISREL 8.8, Scientific Software International. Inc., Lincolnwood, IL. from http://www.ssicentral.com/lisrel/WebH elp/index.htm.

Kelloway, EK. 1998. Using LISREL for Structural Equation Modeling: A Researcher's Guide. Thousand Oaks, CL. SAGE Publications, Inc.

Kostova, T. 1999. Transnational Transfer of Strategic Organizational Practices: A Contextual Perspective. Academy of Management Review. 24 (2). 308-314.

Kurniawan, DM. and N. Indriantoro. 2000. Corporate Governance in Indonesia, in OECD The Second Asian Roundtable on Corporate Governance. OECD. Hong Kong China.

Landis, RS., DJ. Beal and PE. Tesluk. 2000. A Comparison of Approaches to Forming Composite Measures in Structural Equation Models. Organizational Research Methods. 3. 186-207.

Leblanc, R. 2004. What's Wrong with Corporate Governance: a note. Corporate Governance An International Review. 12 (4). 436-441.

Licht, AN. 2001. The Mother of All Path Dependencies: Toward a Cross-Cultural Theory of Corporate Governance Systems. Delaware Journal of Corporate Law. 26 (1). 147-205.

Marsh, HW. and D. Hocevar. 1985. Application of Confirmatory Factor Analysis to the Study of Self-Concept: First- and
Higher Order Factor Models and Their Invariance Across Groups. Psychological Bulletin. 97 (3). 562-582.

Meade, AW., LC. Michels and GJ. Lautenschlager. 2007. Are Internet and Paper-and-Pencil Personality Test Truly Comparable?: An Experimental Design Measurement Invariance Study. Organizational Research Methods. 10. 322345.

Nahm, AY., MA. Vonderembse and XA. Koufteros. 2004. The Impact of Organizational Culture on Time-Based Manufacturing and Performance. Decision Sciences. 35 (4). 579-607.

NCCG. 2001. Code for Good Corporate Governance Ref. 4.0. The National Committee for Corporate Governance.

NCCG. 2004. Pedoman Komisaris Independen dan Pedoman Pembentukan Komite Audit yang Efektif. Gugus Kerja Komite Nasional Kebijakan Corporate Governance.

O'Reilly, CA., JA. Chatman and J. Cadwell. 1991. People and Organizational Culture: A Profile Comparison Approach to Assessing Person-Environment Fit. Academy of Management Journal. 34. 487-516.

Parker, LD. 2007. Internal Governance in the Nonprofit Boardroom: a participant observer study. Corporate Governance: An International Review. 15 (5). 923934.

Perriatt, J., S. Chakrabarty and SA. Lemay. 2007. Using Personality Traits to Select Customer-Oriented Logistics Personnel. Transportation Journal. Winter. 22-37.

Peters, TJ. and RH. Waterman. 1982. In Search of Excellence: Lessons from America's Best-Run Companies. New York: Harper \& Row.

Pettigrew, AM. 1979. On Studying Organizational Cultures. Administrative Science Quarterly. 24. 570-581.

Rahim, MA. and NR. Magner. 1995. Confirmatory Factor Analysis of the Styles of 
Handling Interpersonal Conflict: FirstOrder Factor Model and Its Invariance Across Groups. Journal of Applied Psychology. 80 (1). 122-132.

Raykov, T. and GA. Marcoulides. 2006. A First Course in Structural Equation Modeling, $2^{\text {nd }}$ ed, New Jersey. Lawrence Erlbaum Associates, Inc.

Saffold III, GS. 1988. Culture Traits, Strength, and Organizational Performance: Moving Beyond "Strong" Culture". Academy of Management Review. 13 (4) 546-558.

Schein, EH. 1991. The Role of the Founder in the Creation of Organizational Culture. In Frost, PJ., LF. Moore, MR. Louis, CC. Lundberg and J. Martin (Ed). Reframing Organizational Culture. 14-25. Beverly Hills, CA. Sage.

Schein, EH. 1992. Organizational Culture and Leadership. 2nd ed. San Francisco. Jossey-Bass Publisher.

Schwartz, H. and SM. Davis. 1981. Matching Corporate Culture and Business Strategy. Organizational Dynamics. 10 (1). 30-48.

Semenov, R. 2000. Cross-Country Differences in Economic Governance: Culture as a Major Explanatory Factor. Ph.D Dissertation, University of Tilburg.

Silverzweig, S. and RA. Allen. 1976. Changing the Corporate Culture. Sloan Management Review. 17 (3). 33-49.

Steiger, JH. 1990. Structural Model Evaluation and Modification: An Interval Estimation Approach. Multivariate Behavioural Research. 25 (2). 173-180.
Trompenaars, F., and C. Hampden-Turner. 1997. Riding The Waves of Culture: Understanding Cultural Diversity in Business 2nd ed. London. Nicholas Brealey.

Van den Berg, PP. and CPM. Wilderom. 2004. Defining, Measuring, and Comparing Organisational Cultures. Applied Psychology: An International Review. 53 (4). 570-582.

Van den Berghe, LAA. and A. Levrau. 2004. Evaluating Boards of Directors: What Constitutes a Good Corporate Board? Corporate Governance. 12 (4). 461478.

Van Muijen, JJ., P. Koopman, K. De Witte, G. De Cock, Z. Susanj, C. Lemoine, D. Bourantas, N. Papalexandris, I. Branyicski, E. Spaltro, J. Jesuino, JG. Das Neves, H. Pitariu, E. Konrad, J. Peiro, V. Gonzalez-Roma, and D. Turnipseed. 1999. Organizational Culture: The Focus Questionnaire. European Journal of Work and Organizational Psychology. 8 (4). 551-568.

Wilderom, CPM. and PP. Van den Berg. 1998. A Test of the Leadership-CulturePerformance Model within a Large Dutch Financial Organization. In The annual meeting of the Academy of Management: Best paper proceedings. San Diego, CA. S Havlovic

Wilderom, CPM. and PP. Van den Berg. 2005. Do Transformational Leadership and Organizational Culture Affect Organizational Performance? Tilburg, The Netherlands, 26 April 2005. 